\title{
Reflection of National and Cultural Identities in Foreign Schools of the Kurdistan Region/Iraq
}

\author{
Sangar Youssif Salih, Abdulsamih Muhammad Rahman, Jihad Kamal Othman \\ Salahaddin University, Erbil, Iraq \\ Email: sangar.salih@su.edu.krd
}

How to cite this paper: Salih, S. Y., Rahman, A. M., \& Othman, J. K. (2017). Reflection of National and Cultural Identities in Foreign Schools of the Kurdistan Region/ Iraq. Creative Education, 8, 1135-1154. https://doi.org/10.4236/ce.2017.87082

Received: April 24, 2017

Accepted: June 20, 2017

Published: June 23, 2017

Copyright (c) 2017 by authors and Scientific Research Publishing Inc. This work is licensed under the Creative Commons Attribution International License (CC BY 4.0).

http://creativecommons.org/licenses/by/4.0/

\begin{abstract}
The Qualitative research method has been used to analyze 16 semi-structured interviews. This study focuses on the influences of foreign schools on Kurdish national and cultural identity in the Iraqi Kurdistan region. The study asks how the Kurdish national identity and its components have been reflected or dealt with in the schools' curriculum. The study asks such questions as: Do foreign schools in the region have a special strategy to protect Kurdish national and cultural identity and do the students' parents' opinions matter in framing their children's identity in the foreign schools? Through analyzing the data, the paper finds that learning second languages is important and can be useful for the future of the students. But, Kurdish as their mother language and as an important part of their identity won't be protected and taken seriously to be a scientific language. We also find that hard science classes are taught more compared to the social and historical classes which include more subjects on Kurdish culture, history, and geography that can keep them updated about their national identity in general. Moreover, parents of the students who are enrolled into the foreign schools are not satisfied with the activities and practicing Kurdish national holidays. Creating a globalized generation is one of the positive goals of the schools which were identified from the study. They also do obey the laws that have been issued by the parliament of the Kurdistan region in general. Finally, family can be seen as one of the most influential tools for making or protecting national identity, which can also be seen as more important than the schools.
\end{abstract}

\section{Keywords}

National Identity, Kurdistan, Education, Kurdish Culture

\section{Introduction}

There have been so many studies on the role of education on the creation of na- 
tional identity thorough schools (Brown, 2007; Tormey, 2006; Darr, 2011; Wyse, 2008). In the Kurdistan region of Iraq, nothing scientifically has been done in this regard. And the gap in the literature on this topic should be filled due to the importance of the region and its educational system and national sects. The education system of Iraqi Kurdistan has been under threats since the uprising of the people in the 1990s against the regime of Saddam Hussein. Saddam tried to deny the Kurds as a nation in Iraq and the education system was a part of the process that was put under his control (Abdulla, 2009). Researchers have proven that national identity and education are strongly correlated and affected by historical, economic and social factors (Wyse, 2008). After two decades of being semi-autonomous it is unclear how the region plans to maintain or keep national and cultural identities, especially when it comes to the education system as a crucial tool for keeping its citizens' national and cultural identities as most of the countries do in the world (Tormey, 2006).

Even though having foreign schools in a country can reflect negatively or positively on the nations' cultural and national identities, it is unclear how this goes on in Iraqi Kurdistan. The Kurdistan's Parliament regulated the foreign schools in 2012 by issuing a law establishing that they cannot be a threat to Kurdish culture and identity. It seems that it is time to examine this subject while the Kurdish politicians recently intensify their efforts towards independent state for Kurdistan. Then the Ministry of Education also issued a statement and implemented the law in the schools in the entire region. Moreover, the region has a large number of foreign schools; they all have their policies and philosophies in education. According to the general director of education in Erbil governarate, only in Erbil, 15 foreign schools exist. This paper tries to reveal what these schools are doing in the matter of national and cultural identity. For example, the paper asks whether or not they are threats to the cultural heritage and national indetity of the new Kurdish generation or if they play a positive role in this regard. More precisely, the study seeks to answer:

How the Kurdish cultural and national elements reflect on their curriculum?

How their philosophy goes with the Kurdish culture and identity?

How students' parents rate the schools' concerns of keeping and teaching Kurdish heritage and cultural and national identity?

\section{Relevant Literature}

Society can remain only when it has a variety of differences and similarities inbetween its members (Durkheim, 1972). One of the tasks of national identity is promoting the similarities between members of a community (Smith, 1991). Other researchers also have said that national identity can be built through encouraging equal citizenship rights, so that other cultural, ethnic and national differences can be merged into one national identity and culture (Unal \& Inac, 2013). National identity gets created by three basic elements, which are social, ethical and formal elements. Also, all of the members of the community hold the same identity without considering other ethical or curtail differences (Kellas, 
1991). At the beginning of this process, education should promote the similarities and sameness of the society to the children's in the society (Durkheim, 1972; Smith, 1991; Tormey, 2006). It's also associated with the theory of socialization process in which countries try to utilize on their generations through schools, especially the private or internationals schools to make a proper national indemnity for their follow citizens.

National identity is one of the abstract and complicated concepts that researchers have not agreed upon a definition. However, in general, national identity is defined by a nation's material and non-material values and norms which is the same as national culture to create national identity. As a result national identity includes: language, flags, history, lifestyles, building designs, arts and music (Wodak, Chllia, \& Reisigl, 1999). Smith thinks that a type of nationalism has ethical and civil elements at different levels and in different forms (1991). The civil and regional elements of national identity can be more powerful than issues about location or residency. In fact, some thinkers insist that ethnical and national elements make up national identity. According to Smith, from the two mentioned elements of nationalism, two kinds of national identity can be derived. The first model is the civic-territorial model, which requires a shared social, geographical and cultural component. Contrary, the second element is an Ethnic-Genealogical Model. National identity in this model relies on shared ethnicity, blood ties, and nationality where these elements combine to protect and maintain the desired identity.

Nowadays, national identity represents people's identities for the most part and it identifies different kinds of groups. While some of the other elements of identity can be changed or affected the "national identity" remains the same. (Greenfeld, 1996). Likewise, Smith also thinks that national identity is the basic tool for keeping people together and developing shared values and culture. These elements create a collective social and economic identity for a group of people (1991). However, some other thinkers say that national identity is a continuous process that always re-defines itself (Schlesinger, 1987). As a consequence, national identity can be created through the process of socialization (Unal \& Inac, 2013). The theorist Ernest Gellner believes that there is a relation between national identity and the educational system. He argues that when society transformed from an agricultural base to industrialization, a cultural change occurred which he calls "High Culture." He argues that this culture should protect national identity. Gellner maintains that education is the key element in maintaining and creating this national identity (Gellner \& Ernest, 1983). This is why some countries rely on the educational system to promote a strong national identity and socialize successive generations through education (Darr, 2011). In the United Arab Emirates, the government has used education to create a national united identity and common culture. Moreover, the citizens are also a part of the global citizenship along with their national identity (Abu Dhobi Education Council, 2014). In the Kurdistan region of Iraq, using the education system to empower the national identity started from the beginning of the 
90s. Abdulla argues that the aim of this process was to promote a nationalist identity through the educational system to make a nationalist individual through education process (2009).

\section{Language and National Identity}

People have their individual understandings about their own language. Consequently, this understanding leads them to have common values and shared behaviors with others in the society. Blommaert calls this understanding the ideology of language (2006). Language creates reality and sometimes can be a reflection of reality; that is how effective language is on our thoughts and opinions (Pavlenko, 2003). This is why scholars are concerned about language and its use particularly in education and many promote the development of a national dialect. Some thinkers even say that if there is not an investment in language for students, learning will fail and not succeed (Norton, 2013).

Some researchers emphasize the importance of language in nation building. This idea refers to the Germany theory of Language-Nation. Supporters of this theory think that language creates similarities between people, and helps unite them around similar interests. Others say language is the main element of a nation. For example, according to Ali people who are in groups and share a common language can be called a nation due to the similarities in the language (2004). Moreover, any language holds the culture of a nation through education. In effect the mother language is the tool for maintaining and improving the culture. The opposite can also be true where foreign languages can harm a nation (Abdulla, 2009).

There is an association between learning a second language and national identity. In some countries; such as Russia, the government intervenes on language matters and tries to protect its nations' national identity. Also the subjects are more related to communism (Pavlenko, 2003).

In an ethnographic study, Clemente and Higgins in Oaxaca City in Mexico found that local English teachers had found a good way to protect their local and national identity without harming their students. They created the idea that learning a second language is a part of culture but should protect their language at the same time. They also showed their students that learning a language does not mean that they have taken and learned the culture too (2009). In Kurdistan, studying in Kurdish has been a challenge for the Kurds, but now it is an official language in schools in the entire region. This has led the people of the region to go to school and be more literate than before (Abdulla, 2009).

\section{National Identity and Curriculum}

One of the mechanisms that has been used in educational systems to create or improve national identity is curriculum. Kim thinks that when we want to understand a nations' national identity, we have to evaluate its national curricula (2004). Researchers also point out that the social sciences and humanities have a major impact on national and cultural identity through the educational curricula 
in schools (Kim, 2004: Wyse, 2008). According to Phillips et al. nationalist ideas can be part of most subjects in a school's curriculum, but history seems to be the class where nationalism and national identity can be most promoted (1999).

National identity has been reflected on in most countries' national curriculums in order to protect their identities. For example, education policy in Japan, which is called (Monbusho) is based on respect and love in order to protect Japan's national identity. Respect here means that the students should have respect for their language, culture and history. And love means that students should feel that they are Japanese and promote coexistence in the country. We also see how nations try to teach their generation's art, music, history and laws so they can remember where and whom they belong. This is a kind of policy that Parmenter found in his study (1999), in which the Japanese students were asked to rate their Japanese-ness from $(1-5) .70 \%$ of the students said they are Japanese because they were born in Japan and rated themselves at 4 and 5. Here we see how they stated that they belong to their country, and being Japanese is being proud. This is an outcome of an educational system that cares about national identity.

In a study conducted by Wyse, the researcher interviewed teachers who teach social science classes. The study found that social science classes are very effective platforms or venues for strengthening the national identity of students (2008). Thus, we see how important the role of curriculum is in creating national identity. Another example is a country like China. China has been successful when it comes to the connections between national identity and curriculum of schools (Darr, 2011). In the Philippines, when the politicians and policymakers found out that their new generation did not have a strong national identity, they started a new class called Ethical Education in 1989 which promoted better and stronger national identity in the country (Almonte, 2003).

Turkey also can be seen as one of the successful countries that uses the educational system to build a nation with a strong national identity. It can be seen that simply being Turkish has been prioritized on the curriculum and other minorities have not been mentioned (Ince, 2012). Jordan also has been using the education curricula to reinforce its national identity. In Jordon the government uses the schools to promote a form of citizenship that loves and respects the culture and the country (Eid, 2015).

The Baath's era in Iraq was not good for the Kurds. Their nationality was under attack and so many plans were implemented to weaken it. The regime used the schools curricula to Arabize the Kurdish areas and people. This is evidenced by what happened after the collapse of the regime when the KRG changed and renewed the curriculum and added history and geography etc. The KRG made the school curriculum favor the Kurdish national identity. But, according to Abudlla the schools in the region have not been a good player in this regards, especially the foreign schools that can be seen as a threat to the Kurdish national identity (Abdulla, 2009).

\section{Globalization and National Identity}

Researchers think that education should have its answers to this century due to 
the economic, political and social changes in the $21^{\text {st }}$ century. The societies need new forms of identity; so having an education system that reconstructs the national identity is needed (Parmenter, 1999). Researchers also say that the characteristics of the national identity change continuously because issues of ethnicity and traditional identity never remain static (Resnik, 2006). The effects of globalization on national and cultural identity are also major factors because theydrive the whole world toward a more similar and uniform culture (Wieviorka, 1998). Some thinkers say that a global nationality may one day replace local, ethnical and regional national identities resulting in many people giving up their own national identities for a global one (Unal \& Inac, 2013).

Pike (2000) thinks that teachers in this global education have a type of global educational culture. For Pike this type of education provides the students with Multiple-perspectives that lead them to think and be more open to international ideas and different cultures. As a result students will be more inclined to go aboard and transcend their local and regional realities for a global one. In other words, here education provides a new way or lens for looking at the world and improving all humans' lives. Pike sees these characteristics in the Canadian and British educational systems.

We see that Israel is one of the countries that changed its system from one focused nationally to one focused on a more diverse and global education system (Resnik, 2006). Chnar in her study found that the Kurdistan region and its education system have reached international levels when it comes to spreading and supporting global education. She also claims that as a result of these changes the region has neglected its own national identity while the nation is under threat regionally. She thinks that the education system in the region is not focused enough on making the present generation put their Kurdish identity first, which she claims the region needs for its survival (2009).

\section{Data and Methods}

There is no right or wrong method for doing scientific research. The nature of the study usually determines what kinds of methods should be used in the study (Silverman, 2013). The justification for using a qualitative or quantitate method is normally determined by the types of research questions and problems that will be investigated in the study (Vanderstoep \& Johnston, 2009). Due to the nature of our questions in this paper, we have used the qualitative research method to investigate how foreign schools in the region teach national and cultural identity. As Marvasti (2004) states this kind of method provides detailed and descriptive research results.

Semi-Structured interviews were used to conduct the research; this kind of interview is popular in qualitative studies nowadays. Different people were interviewed in order to obtain different ideas and opinions on the issue (Marvasti, 2004; DiCicco \& Crabtree, 2006). 16 interviews were conducted with 4 school principals, 5 teachers, and 7 parents at 6 different schools. Based on established standards for these types of studies the researchers (we) used the interviews for data collection. We followed established methods that show that the number of 
interviews always depends on the themes that emerge from the interviews (Baker, Edwards, \& Doidge, 2012). The most important questions that were asked of the participants were: 1) the role of Kurdish national identity in foreign schools plans and curricula 2) how they care about Kurdish national holidays and activities 3 ) the role of foreign schools in addressing global national identity.

Researchers emphasize that qualitative studies normally rely on the different methodologies of Purposive Sampling or Non-Random Sampling (Vanderstoep \& Johnston, 2009). Thus, we have randomly picked 6 schools in Erbil city, the capital city of the Kurdistan region to conduct our research. Most of the foreign schools in the region are located in Erbil. The participants of the study were selected purposefully. Teachers, principals and parents were chosen because they have some awareness of the issues and have a willingness to talk about the research problem. To protect their privacy, pseudonyms have been used and the participants have given permission to be interviewed and have their voices recorded. The interviews were conducted at the locations that they preferred. Most of the interviews were conducted in schools, homes and workplaces. The interviews took about 20 minutes each.

Thematic analysis is a proper way of analyzing interviews in qualitative studies (Neuman, 2014), and the goal of this research agenda is making meaning out of the data (Silverman, 2013). All of the interviews were transcribed and the themes have been taken that are important and clear for the researchers.

\section{Research Limitations}

Due to financial limitations, the study could not survey a larger sample that could have been more useful to take participants in all different cities of the Kurdistan region. The researchers also could not interview all the people that they wanted because not all of the schools allowed the researchers to interview their staff nor ask the parents to come to have an interview. Some schools only allowed the teachers and some only the parents. As a result this made the data collection process difficult and more complicated. Thus, we could only collect data from certain people and not from all of the members of the foreign schools in the Kurdistan region.

\section{Conclusions and Discussion}

Throughout the interviews, five themes emerged. These central themes are 1) language 2) curriculum 3) national identity in the foreign schools' programs 4) the foreign schools' implementation of the KRG education laws 5) family's role in making national identity. Through these themes, we have attempted to show the results of the study and see how the national identity is reflected in these foreign schools' programs in Erbil city.

\subsection{Language}

Language is one of the most important components of a nation. Language shows a nations' existence (Ali, 2004). Language has been studied along with identity; 
that is why some researchers think that learning second languages can be a threat to a nations' identity (Abdulla, 2009). The Kurdistan region has easy policies for opening a foreign school. Here we discuss three sub-themes about language, which are:

\subsubsection{Language as a Capital for the Students}

Language can be seen throughout the interviews as one of the most important factors behind sending students to the foreign schools by their parents. The parents see the second language as an opportunity for their future lives. For example, Aras, who has 2 children in C school, says:

"We were in Slemani city, we saw how those schools get opened and popular, we felt how the language important is, then we sent our kids to those schools".

We see that the establishment of those schools provided the parents an opportunity to invest in their children' education, especially second languages. They see how language is important and the most popular language is English as we see form their quotes. The parents reported that they see English language as one of the capitals for their children in their future in the Kurdistan region.

Another parent named Azad who has a child in F school states that he sent his son to learn the second language, which says:

"Always send your kids to somewhere that can learn a second language. I sent my son only to learn the second language; I have visited the school twice this year to let them know to teach my kid as many languages as possible. We have the freedom of learning our own language, so we have to learn others' language as much as we can through education and schools".

Here, we see how this father motivates and favors learning the second language. He encourages his son to learn French and to be in touch with the French teachers. He sees how important the language is for his future. What is interesting here is that the father does not have any of these credentials but he wants to make sure that his child has a second language aptitude. This is how learning a foreign language is reported in our interviews. Moreover, the parents do not fear the second language on their native language at all.

Again, Hemn who has a child in E school who is learning a second language. He states:

"Learning a second language in public schools puts extra responsibilities on parents, so I enrolled my kid in the private foreign once".

We can see that this father values learning a second language and sees how his child can learn a second language in the foreign schools better compared to the public one. And having these foreign schools offer different languages provides the parents opportunities to invest in their children.

The importance of learning second languages also has pushed the parents to even value the other languages more than their native language. As Hangaw, a teacher in E schools says: 
"I have seen parents here only to talk to the English teacher to see the performance of their kids in English class, they never ask the Kurdish class teacher to see how their kids do in it. That is how they value the second language rather than the native".

Here, we clearly see how the parents value the second language. We see that they feel their children do not need to use their native language in their education since they have learned from home. While researchers have found that learning a second language can be a threat to the mother tongue (Abdulla, 2009), many parents do not have any concerns about this issue.

In conclusion, we see that the parents of our sample value and invest their children in learning a second language. They are fully aware of the process because they can have better opportunities in their future; the schools have also given what they need to the investment. The reason behind this is the parents know how second language acquisition can help their children in finding jobs in their future. Studies also confirm that knowing a second language raises your chances of obtaining a job more than those who only know one language (Dustmann \& Fabbri, 2003). This shows that the Kurdistan region has become an open place and region for the foreign schools to invest in the education sector and the Kurdish people have interests to teach their children a second language. But, the threat that we find would impact the Kurdish language not only in schools but also in the labor market and most other aspects of life.

\subsubsection{English as the Second and Scientific Language}

According to our data, most of the schools in Erbil have used English language as their primary language and the parents also confirm that. This shows that English language comes first on the list of languages in the foreign schools in the Kurdistan region and most of the students want to study the language. Most of the centers, universities and private institutions announced English as their main language which leads the parents to value English as the most useful language for their children. So they encourage their children to go to the foreign schools. As Aras, who has 2 children in C school states:

"The subjects that those schools cover are good and very useful for the students, those schools play a positive role when it comes to science in the region. The students academic performance can be seen like other international students or even better than other students".

This father sees the relations between the second language and the students' academic performance. He does not care if his children learn their native language or not. Kurdish is not the scientific language. Some of the parents even see the English language as the second language in the region due to its popularity. As Hemn from E school says:

"I have enrolled my kid into the foreign school to learn English, it is the most popular language in the world and can be called the second language in the region after Kurdish". 
Some other parents in the study mention that they have lived in other western countries and when they returned to Kurdistan they wanted to enroll their children in these schools. This is because their children can adapt in these schools' system easier than in the public ones. For instance, Ashti who has a child in a school says that he has sent his children to the foreign school due to the language for the most:

"One of the reasons behind sending the kids to this kind of schools is learning the language. The system also hooked us to do that too because they can adapt easier than those public schools. We have looked and asked to see what is the best option to our kids, most of the friends recommended the school A as the best option. The language is English and the system is like the European once".

These factors that we have discussed above show how important the second language is for the parents. They care about learning the second language for the most in the region and we can see how popular English is. We have to confess that learning the second language has been in place in most of the countries curricula but it should also be seen as a threat to the local culture and language (Pavlenko, 2003; Clemente \& Higgins, 2009). The parents that have been interviewed do not have a clear perspective to make a balanced decision between their children's native and second language learning. None of the parents talked about how they try to keep their children's native language safe. None of them tried to make the balance but care about learning the English language. They do not seem to be observing their children's Kurdish language skills. That is how we see the English language's effects on them for the long term and how this situation can be seen as a threat to the Kurdish national culture and identity.

\subsubsection{The Importance of Kurdish Language}

The ministry of education in the Kurdistan region has its plans and implementation to protect the new generations' identity through studying the history, language and geography of the Kurdistan region. The ministry also has issued laws which will require that the next generation must study their own language, despite the foreign language. This means that the mother language is protected. Most of the interviewed teachers in our sample state that they do try to protect the Kurdish language and teach the students their own language. As Halder from A school says:

"The Kurdish teacher cares about the language even the main language in the school in English and the curricula is in English".

This means the Kurdish teacher has to teach the students the same materials that the public schools cover. Thus, we see how the government encourages them to be in touch with the Kurdish language rules. As Gaylan, the director of $\mathrm{C}$ school says that social sciences, region and Kurdish language classes are taught in his school:

"Our main language in school is English but we give the students Kurdish 
too, we have Kurdish language, religion and humanities classes in Kurdish here. The rest is in English and comes from Cambridge”.

The only classes that are not taught in Kurdish are the hard sciences where most of the participants of the study think that the schools are not a threat to the Kurdish language. As Arash who has a child in C school says:

"As a father who has a child in a foreign school, I am satisfied with what they do with the language, they teach Kurdish and follow the rules of the ministry of education. I see that they learn their native language, they keep their heritage and culture, the ministry forces them to remain like that".

The above statement shows that there is an attention to the Kurdish language in the schools, and the ministry of education for the most has brought that. Some of them mention that they keep the language days active and Kurdish is a holly language for them. We even find that some of the foreign teachers care more than the national ones when it comes to celebrating the Kurdish language day. As Bahzad in A school says:

"We have languages day here, we do celebrate and remember all the languages, but we have emphasized on Kurdish. When we started, we forgot to have a Kurdish flag in the ceremony, then we brought and respected the Kurds and their heritages".

Most of those who think that the Kurdish language is taken care of in the foreign schools rely on the law of ministry of education. As Zewar from B school who teaches Kurdish language says:

"Kurdish language has its importance here, we do teach the same as the public schools here".

But, Goran who has a kid in A schools says:

"Kurdish is taught in those schools along with the other languages, but that does not mean that the students care about their native language more than the other languages".

What is clear here is that the Kurdish language is taught and it's an important class in the foreign schools. And that may be a result of the regulations of the ministry of education that obeys them to teach the language. What is not clear is that how the teachers teach the class and how it goes. Having the class is not enough to make a decision on the matter, the teachers' role is important too. Thinkers also say that the teachers role in giving or passing a message is important in education programs (Wyse, 2008).

\subsection{Curriculum}

Another theme that emerges in this study is the influence of the curriculum on the national and cultural identity in schools. Each one of these schools has its own programs and agendas, so the reflections of the programs can be seen on 
the students easily which was confirmed by the parents. This theme is discussed in two sub-themes that are:

\subsubsection{Cultural and National Identities within Textbooks}

There are two ways of evaluating an education system to see how it protects a nation' culture and heritages; the first is the textbooks (Kim, 2004). In those foreign schools, all of the hard science subjects are taught in English and none of them include anything about Kurdish culture and history as the directors and teachers say. As Kazhal who is the principal of B schools states:

"None of the hard science classes has subjects on the Kurdish culture and national topics..."

According to the laws of the ministry of education, all the schools should teach Kurdish, humanities and human wright classes. As (Wyse, 2008; Kim, 2004) find that the social science classes has a huge impact on the students to have a certain national and cultural identity. Most of the participants in our sample stated that they follow the rules and teach them in Kurdish. As Dildar from A school says:

"Our school is private, but we go by the public rules, we teach Kurdish language, humanities, human right, music and art in Kurdish and similar to the public schools".

English language class in those schools is the main class but it has nothing to talk on Kurdish cutler and history. In most of the other countries the textbooks have been localized so the students can have their own identity (Clemente \& Higgins, 2009). As the students' father observed that those textbooks are brought from other countries and have not been localized with Kurdish topics. As Hemn who has a kid in E schools says:

"The stories on the English language class textbooks are all from west and none of them talk about a Kurdish story, the schools should have put stories of Kurdish leaders and uprisings instead".

The second way is observing the way of teaching (Pedagogy). In order to understand how the teachers teach in the classes, the researchers should have been inside the class but that was not possible due to lack of permission. So we tried to see what teachers and parents think about this and we have looked at the data to discover their perceptions. Some of the teachers and principals state that they have taught all the classes in a way that Kurdish culture and identity aspects are protected. As Liza, a principal from D school says:

"We teach some British values here but have dedicated the other rest of the curricula to the Kurdish culture and heritage. We do have localized our education system to a Kurdish one. Our education system has adapted with Kurdistan. We study the history of the cities and culture, we do celebrate the holidays and remember all the tragedies that the nation has faced".

On the other hand, it is clear that the language of the teaching plays a big role, 
so what the parents here tell that those classes which are in Kurdish do not cover subjects on Kurdish history, geography and culture. This does not encourage the students to be familiar with their national and cultural identity. Goran who has a daughter in A school says:

"My kids do not have tensions to stay or enjoy the life here, they are intended to go to the other countries, and they have not been to Slemani nor Duhok which are Kurdish cities. They do not want to visit them at all”.

As (Parmenter, 1999; Wyse, 2008; Darr, 2011) studies support the argument for constructing national identity through the education system and how these programs of education can affect the generation to a certain national identity. Throughout our data, it shows that these schools do not have a clear strategy to protect the nations' identity, nor the programs or textbooks of the schools.

\subsubsection{Hidden Curriculum and National Identity}

Hidden curricula refers to all of the plans and strategies that schools use in order to implement a certain ideology to make a specific identity and a personality of opinion for the students in their education process (Sadker, Zittleman, \& Sadker 2012). The schools staff and people talked about how they care about learning and not other secondary plans. Most of the teachers also stated that they do care and respect the Kurdish culture. Also they wanted to change some Kurdish cultural aspects and values and bring new international standards to the Kurdish students. As Karwan who is a teacher in C school state:

"I want to be frank with you; we have bad values and behaviors that should be changed. We do throw things on the streets, we do deceive in schools, we do not have lines when we get or buy things. Yes, we need a change and all those bad values should be replaced with international good once. We need to re-correct ourselves...”.

Most of the parents say that there is not a certain plan to create a national Kurdish identity for their children, but they have felt some efforts that are in place with their children kids to have a feeling of belonging to the nation and country. As Hemn who has a child in E schools says:

"There is not a program that lead the students to feel their identities....".

Goran as a father also says:

"I feel a hidden curricula behind my kids' education, they want my kid to have an Islamic personality though teaching Quran and praying”.

Also, Ashti who has a daughter in A schools state:

"If you look at the plans and programs of those schools, you would see they prioritize some things more some other important things. If my kid does not get asked to wear Kurdish clothes, she would not do that because she has not been taught that. But, I see some other religious aspects and behaviors on her that can be clearly see she has been taught in school. Yes, I feel 
on her education but it's really slow with plans".

Knowing how these schools work on the students' identities is an important mission for the parents to understand because it is really complicated and hidden and they should be fully aware. The differences between the schools also should be taken into consideration because some of them teach values and behaviors that go with the Kurdish local culture. But, some of them are different and do not fit to the Kurdish society and can be threats to the nation.

\subsection{The Reflection of Identity on the Holidays and Celebrations}

The Kurds as a nation have always remembered and celebrated their historical tragedies and national holidays which are known to be an element of national identity (Low-Beer, 2003). Most of the teachers and school principals said that they do celebrate the national holidays and remember the historical days. But, there have been different understandings and interpretations on what these days and holidays mean in the interviews. Most of the teachers and school staff stated that they do care about the holidays. As Hangaw who is a teacher in E schools states:

"We have activities in all national holidays, we teach then what those days means to the nation. How we came to here and where do we go in the future...".

Liza also from D school who is a principal says:

"We do have off days in the holidays that ministry of education requires by the law, but not all of them. We do celebrate Nawroz, other Eids and workers day. For example, we try to teach the student what happened in March of 16 every year".

But parents say something different to what the teachers said, for instance, Hazhar who has a kid in A school states:

"They do celebrate the holidays and ask the student to draw picture in those days to express the meanings of the holidays...".

Hemn who is a father of a child in E schools also says:

"The remembering of the national holidays is not that important for those foreign schools, they do not celebrate with deep respect".

The parents' opinions here show that these schools practice and respect the national holidays only because the ministry of education requires them to do so, otherwise; they would not celebrate nor respect these days. Even though the schools celebrate the holidays but still the parents think that they do that only to make themselves acceptable by the people and they do this only for the business. Most of them said that the schools look at these holidays as secondary priorities. This can also be seen in the schools staff interviews too. As Karwan who is a teacher from C school says: 
"I do not think we need to be that serious on national identity while our focus is on academia and science. But still we have Flag Day, the humanities classes are dedicated to Kurdish identity. We have other kinds of students from different ethnicities, so I do not have any perspectives to the nation land cultural identities, our school is diverse and I do not need that".

\subsection{Making a Global Citizen}

Another theme that comes out from our interviews is the role of these schools in creating a citizen that is more global than local. Most of the parents and teachers think that these schools can have a role in creating a citizen a citizen that feels and belongs to the global. This kind of citizen accepts modernity and the values of coexistence, justice and respect without considering others' skin color, race, gender or religion. Aras who has 2 children in C school explains;

"As a father, I do agree with this kind of education that makes our citizens to be globalized, either one American or European or any other countries is acceptable. We can have this kind of education system and protect our identities at the same time. We are all humans and can live together on earth".

It is not surprising that a father thinks that having an education that creates a global citizen because he wants to live with other nations and people peacefully. He says that we are all humans and belong to each other; he sees the common characteristics of all humans. He also thinks that the nations' national and cultural identities can be protected while being in touch with others because he knows how culture works and how it can be used to make our communities better.

On values like modernity and equal rights, he thinks that these schools have been doing well because they do believe and practice gender equality in their schools. He says:

"I see positive signs from those schools when we take gender equality into consideration, they have created a sphere that all the different religious, nation and cultural backgrounds live others without any major issues".

That is what the modern and liberal education focuses on in education, and this is why they have established UNSCO which is an international NGO (Barrett et al., 2006). He also talked about how the Kurds as a nation have suffered for a long time and faced genocide and discrimination; so we all need to avoid these actions and should promote peace and coexistence. This shows how he likes to live and acculturate with others, and how he likes the way that these schools operate when it comes to tolerance. He also says:

"We are a nation that has face so many ways of genocide, we need to promote peace and multi-cultural society. We need to accept all colors and kinds of nationalities".

Again, regarding the role of foreign schools in making global citizens in the 
Kurdistan region, Gaylan who is a principal in C school thinks that we all should try to make that happen along with the national identity. He states:

"Here, people try to make a global citizen while Kurdish, that means we try to make that happen through curricula and programs so we can have a global citizen and Kurdish at the same time".

Thus, having the balance between Kurdish and global citizenship should be taken seriously so that the generation can be Kurdish and globalized. Moreover, Media who is a teacher in a school also sees global education and citizens as important for the region. She says:

"There should be a balance in-between the local and global identities, sometimes those sides presented here differently which should not be".

Here, we see how this teacher defends both the Kurdish and global identities. She thinks that they both should be taken care of and protected so that peace can be promoted and we all can live together in a better way.

By looking at these quotes, we see how these schools play their roles in creating a global identity for the student that should be looked on positively. But, we should not forget the fact that our culture and identity could be forgotten, especially now that the Kurdish identity is under threat. Most of the countries try to implement an education system that creates global citizens. For example, Malaysia in 1983 created a program in their education called Moral Education in order to make the Malaysian citizens be global and know the values and norms of modernity (Hoon, 2010). The United Arab Emiratis also tried to have an education system that promotes global citizenship and those values that are acceptable in the world in general and protects local identity too (Abu Dhobi Education Council, 2014). That is what Green (1996) talks about and says that global education has influenced many countries while their local identity characteristics have not been lost. As a result we can say that these educational systems try to have their local and national values and norms protected, while promoting international standards of identities and making a global citizen.

\subsection{KRG Policies of Foreign Schools}

Another theme the researchers noticed in the interviews was the schools obedience to the KRG's education policies. The ministry of education has its rules and laws for these schools; the data shows that they follow the rules. Dildar who is a teacher in A school says:

"We do go to the general dictator of education in Erbil twice a week to get updates form the ministry of education".

His quote shows that they try to follow the rules or orders in the new regulations. It shows how they follow the rules because he says that they follow orders and new regulations. Liza who is a principal of D school discussed their follow ups with the ministry of education and states: 
"We do follow all of the rules and commands form the ministry of education here in Kurdistan even we do not like all of their rules but we do follow for the most. While we keep our international rules and standards. We try to convince them and show them that we do care about the KRG rules".

We see here that Liza does follow the rules but that she is uncomfortable with some of them because the foreign schools want to keep their international rules at the same time. Aras who is a father who has children in the schools confirms their implementation of KRG rules and says:

"I see those schools adapt and want to work here by the rules, I feel that they care about our laws and I have visited them and asked my kids; they do well everything".

Even though Aras does not talk about the rules and orders directly he explains that they do obey the laws here if the KRG requires them officially. Also, they do care about Kurdish culture and national identities. Overall, the schools try to adapt and be acceptable by all, they follow and practice the laws that the ministry of education issues.

\subsection{The Role of Family in Making Cultural and National Identity}

Throughout the interviews the role of the family has been discussed in a way that most of them directly or indirectly see the family as a social institution to improve and create national identity. As can be seen from Aras's quote:

"In fact, beside what we have here in schools to make the national and cultural identities, family can take a part of the responsibility. We have schools that kids take science and education from, family can give culture and identities too".

This quote shows that schools are not the only institutions to take the responsibilities when it comes to identity. The family also takes part and some of the participants mention that families can contribute to the process of identity creation. He also says:

"We have lots of Kurdish immigrants in overseas, such as USA, UK and other countries but we should see how they raise their kids when it comes to identities. I know Kurdish families who live in the US and raise their kids in a way that you can see their Kurdish identity signs clearly. We have to be proud of them all the time because they keep the heritage and culture while they live in another country".

Goran as a father also thinks that parents' awareness plays a huge role in their identity creation because their level of nationalism can affect the children. He also says that schools cannot do everything and that the parents should take part. Goran says:

"National education has been left in the schools for parents, if the parents are not aware of it, the kids would not be nationalized well. We should not expect the foreign to give a national education to our kids". 
This father has the idea that private schooling cannot raise and make a generation that can be nationalist because they promote global ideas. He states that we should not expect the teachers to make the children nationalist and keep their national and cultural identities at the same time.

Again, on the role of parents in identity creation and their awareness, Aras says:

"The students stay in schools for a few hours but at home for longer times. They get taught science for the most, but we as parents are more responsible. They are with us for 18 hours and we should not avoid what they should know on their national and cultural life aspects. They should know what are the Kurdish history, language and clothes".

Finally, it is clear that the parents' awareness level plays a huge role in identity creation. Even though the students tend to go to school to learn and get educated the parents also have to teach the children knowledge about their national and cultural identity along with the efforts from the schools.

\section{Conclusion}

To sum up, learning the second language can be very useful and advantageous for students from schooling, and also can be seen as a positive sign of education. But, it can be an issue among the Kurdish language improvement and the next generation's national identity. It can also be clearly seen from the quotes that these foreign schools' curricula include the topics and subjects on Kurdish national and cultural heritage which are the same as the public school. However, not all of the hard science classes contents are like the humanities classes. The schools philosophical agendas are more focused on the students' academic performance rather than on national aspects. But, they do care about the holidays and national matters routinely. This has created doubt for the parents that their children do not learn Kurdish heritage and culture. The last finding is that these schools try to create a global identity in the Kurdistan region, which the parents welcome. Moreover, they also follow the rules and commands of the ministry of education when it comes to the curricula and keep the national matters alive. Family also can take part in the processes identity establishment because it is an important part and plays a huge role in filling the gaps that schooling has to make a Kurdish national identity that fits the globe and era.

According to what we have found, it is really important that this study be done in a broader way at a regional level. We also suggest that future researchers and studies should focus on the role of foreign schools on social integration of the students. It is also important that all of the groups and related people take part in the studies, which are more related to the national identities matters. We also suggest that different kinds of methodologies can be used in future studies to have a better insight into Kurdish national and cultural identity issues. Lastly, each of them found through this research could be examined separately.

The Kurdistan region government is responsible to issue laws and policies to 
those schools that mandate them to implement them regularly. We also recommend that the classes and subjects that are more related to national and cultural identity subjects should be taught in a similar way as the other hard science classes, such as, Kurdish language, history and geography etc. The teachers also should be fully aware of Kurdish history, culture and heritage; thus, they have to be trained and have sessions on Kurdish culture and society.

\section{References}

Abdulla, C. S. (2009). Role and Effect of Educational System on the National Dimension in the Kurdish Society. PhD Dissertation, Erbil: Department of Sociology, Salahaddin University.

Abu Dhobi Education Council (2014). National Identity and Culture. https://www.adec.ac.ae/en/MediaCenter/Publications/National_Identity_EN\%20(2)/fil es/assets/common/downloads/publication.pdf

Ali, J. (2004). Nationalism and Kurdish Nationalism. Sulaymaniyah: Ranj Publishing House.

Almonte, S. A. (2003). National Identity in Moral Education Textbooks for High School Students in the Philippines: A Content Analysis. Asia Pacific Education Review, 4, 19-26. https://doi.org/10.1007/BF03025549

Baker, S. E., Edwards, R., \& Doidge, M. (2012). How Many Qualitative Interviews Is Enough? Expert Voices and Early Career Reflections on Sampling and Cases in Qualitative Research.

Barrett, A. M., Chawla-Duggan, R., Lowe, J., Nikel, J., \& Ukpo, E. (2006). The Concept of Quality in Education: A Review of the "International" Literature on the Concept of Quality in Education. Bristol: EdQual.

Blommaert, J. (2006). Language Policy and National Identity. In T. Ricento (Ed.), An Introduction to Language Policy: Theory and Method (pp. 238-254). Oxford: Blackwell Publishing.

Brown, G. K. (2007). Making Ethnic Citizens: The Politics and Practice of Education in Malaysia. International Journal of Educational Development, 27, 318-330.

Clemente, A., \& Higgins, M. J. (2009). English as a Linguistic and Intellectual Weapon against Native-Speakerism. In Selección de artículos del segundo congreso de investigación cualitativa (pp. 155-163).

Darr, B. J. (2011). Nationalism and State Legitimation in Contemporary China.

DiCicco-Bloom, B., \& Crabtree, B. F. (2006). The Qualitative Research Interview. Medical Education, 40, 314-321. https://doi.org/10.1111/j.1365-2929.2006.02418.x

Durkheim, E. (1972). Selected Writings.

Dustmann, C., \& Fabbri, F. (2003). Language Proficiency and Labour Market Performance of Immigrants in the UK. The Economic Journal, 113, 695-717. https://doi.org/10.1111/1468-0297.t01-1-00151

Eid, F. H. (2015). Citizenship, Community and National Identity: Young People Perceptions in a Bahraini Context. Journal of Case Studies in Education, 7, 1.

Gellner, E. (1983). Nations and Nationalism. Ithaca: Cornell University Press.

Greenfeld, L. (1996). Nationalism and Modernity. Social Research, 63, 3-40.

Hoon, C. L. (2010). An Appraisal on the Implementation of Moral Education for Schools in Malaysia. In Proceedings of the 4th International Conference on Teacher Education; Join Conference UPI \& UPSI. 
Ince, B. (2012). Citizenship Education in Turkey: Inclusive or Exclusive. Oxford Review of Education, 38, 115-131. https://doi.org/10.1080/03054985.2011.651314

Kellas, J. G. (1991). The Politics of Nationalism and Ethnicity. Basingstoke: MacMillan. https://doi.org/10.1007/978-1-349-21527-0

Kim, H. (2004). National Identity in Korean Curriculum. Canadian Social Studies, 38, 3.

Low-Beer, A. (2003). School History, National History and the Issue of National Identity. International Journal of Historical Learning, Teaching and Research, 3, 1-6.

Marvasti, A. B. (2004). Qualitative Research in Sociology. London: Sage. https://doi.org/10.4135/9781849209700.n1

Neuman, W. L. (2014). Social Research Methods: Qualitative and Quantitative Approaches (7th ed.). Essex: Pearson.

Norton, B. (2013). Identity and Language Learning: Extending the Conversation (2nd ed.). Bristol: Multilingual Matters. https://doi.org/10.1080/0305792990290205

Parmenter, L. (1999). Constructing National Identity in a Changing World: Perspectives in Japanese Education. British Journal of Sociology of Education, 20, 453- 463. https://doi.org/10.1080/01425699995209

Pavlenko, A. (2003). Language of the Enemy: Foreign Language Education and National Identity. International Journal of Bilingual Education and Bilingualism, 6, 313-331. https://doi.org/10.1080/13670050308667789

Phillips, R., Goalen, P., McCully, A., \& Wood, S. (1999). Four Histories, One Nation? History Teaching, Nationhood and a British Identity. Compare, 29, 153-169.

Pike, G. (2000). Global Education and National Identity: In Pursuit of Meaning. Theory into Practice, 39, 64-73. https://doi.org/10.1207/s15430421tip3902_2

Resnik, J. (2006). Alternative Identities in Multicultural Schools in Israel: Emancipatory Identity, Mixed Identity and Transnational Identity 1. British Journal of Sociology of Education, 27, 585-601. https://doi.org/10.1080/01425690600958782

Sadker, D. M., Zittleman, K., \& Sadker, M. P. (2012). Teachers Schools and Society. McGraw-Hill Higher Education.

Schlesinger, P. (1987). On National Identity: Some Conceptions and Misconceptions Criticized. Social Science Information, 26, 219-264. https://doi.org/10.1177/053901887026002001

Silverman, D. (2013). Doing Qualitative Research (4th ed.). London: Sage.

Smith, A. D. (1991). National Identity. London: Penguin.

Tormey, R. (2006). The Construction of National Identity through Primary School History: The Irish Case. British Journal of Sociology of Education, 27, 311-324. https://doi.org/10.1080/01425690600750494

Unal, F., \& İnaç, H. (2013). The Construction of National Identity in Modern Times: Theoretical Perspective. International Journal of Humanities and Social Science, 3, 223-232.

Vanderstoep, S. W., \& Johnston, D. D. (2009). Research Methods for Everyday Life: Blending Qualitative and Quantitative Approaches. San Francisco: Jossey-Bass.

Wieviorka, M. (1998). Is Multiculturalism the Solution? Ethnic and Racial Studies, 21, 881-910. https://doi.org/10.1080/014198798329702

Wodak, R., De Cillia, R., \& Reisigl, M. (1999). The Discursive Construction of National Identities. Discourse and Society, 10, 149-173. https://doi.org/10.1177/0957926599010002002

Wyse, J. L. (2008). Teachers A Perceptions of the Construction of National Identity through the Primary School Social Studies Program in Malawi. 
Submit or recommend next manuscript to SCIRP and we will provide best service for you:

Accepting pre-submission inquiries through Email, Facebook, LinkedIn, Twitter, etc. A wide selection of journals (inclusive of 9 subjects, more than 200 journals)

Providing 24-hour high-quality service

User-friendly online submission system

Fair and swift peer-review system

Efficient typesetting and proofreading procedure

Display of the result of downloads and visits, as well as the number of cited articles Maximum dissemination of your research work

Submit your manuscript at: http://papersubmission.scirp.org/

Or contact ce@scirp.org 